\title{
Effects of a symbiotic on coccidian infestation and zootechnical performances in broilers
}

\author{
C. Ammari, N.Mimoune ${ }^{*}$, R. Kaidi, M. Melizi and D. Khelef
}

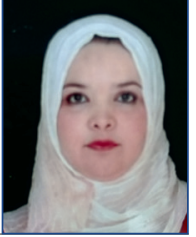

\begin{abstract}
Coccidiosis remains an obstacle for the poultry sector worldwide, including Algeria. In the field of food biosecurity, symbiotics are used with the aim of improving zootechnical performance of chickens, and combatting the negative effects of this parasitosis. This study compared two broiler farms with 12,000 chickens of the Arbor Acres strain, where chickens on one farm received supplementation with symbiotics. Weight of 144 animals, mortality, food and water consumption were measured, and consumption (CI) and conversion indices were calculated. For parasitology, droppings were collected and the intestinal contents of $10 \%$ of animals were collected. Data showed that at 43 days, the supplemented group had a weight of $2750 \mathrm{~g}$ as compared to the control
\end{abstract}

that had a weight of $2630 \mathrm{~g}$, with an average consumption of $4834 \mathrm{~g}$ vs. $5087 \mathrm{~g}$ per animal, CI of $1.62-1.35-0.81$ vs. $1.65-1.52-0.89$, the conversion index of 1.9 vs. 2.07 , and mortality rate of $9.29 \%$ vs. $10.37 \%$, respectively. Oocyst excretion was zero at the farm receiving supplementation vs. 0, 100, and 550 OPG in the control group on days 15, 21 and 28, respectively, parasite infestation was 41,600 OPG, 32,800 OPG, and 30,500 OPG vs. 800 OPG, 1,100 OPG and 1,200 OPG, respectively. For prevalence, several species of Eimeria were identified in the control. The means found in this study support the use of symbiotics, and efforts to improve the formula of the symbiotics should yield even better results.

Key words: symbiotics; coccidiosis; zootechnical performance; infestation rate

\footnotetext{
Chama AMMARI, Mohamed MELIZI, Department of Veterinary Medicine, Laboratory of Animal Health, Animal Production, and Environment (ESPA), Institute of Veterinary Sciences and Agricultural Sciences, University of Batna 1, Batna 05000, Algeria; Nora MIMOUNE*, (Corresponding author, email: nora.mimoune@gmail.com), National High School of Veterinary Medicine, El-Alia, Algiers, Algeria, Laboratory of Biorechnologies related to animal reproduction (LBRA), Institute of Veterinary Sciences, SaadDahleb University, Blida, Algeria; Rachid KAIDI, Laboratory of Biorechnologies related to animal reproduction (LBRA), Institute of Veterinary Sciences, SaadDahleb University, Blida, Algeria; Djamel KHELEF, National High School of Veterinary Medicine, Animal Health and Productions Laboratory, El-Alia, Algiers, Algeria
} 


\section{Introduction}

Global consumption of poultry is constantly increasing (Guergueb et al., 2021). This is due to many factors, including price, changes in tastes, consumer preference, health concerns, and the increase in real disposable income (Brugere-Picoux and Silim, 1992).

The Algerian poultry sector has undergone significant transformation following the economic reforms and the liberation process initiated since the 1990s.Despite this positive development, the production costs of poultry products are at a fairly high level compared to those of developed countries, due to the additional costs of food charges, biological equipment and veterinary products.

In Algeria as elsewhere, the industrialization of poultry farming aimed at increasing animal production is an excellent example of an artificial environment that is sometimes accompanied by a lack of mastery in breeding, increasing the opportunities for the onset of parasitism and contamination of animals (Brugère-Picoux, 1992; Guergueb et al., 2020).

Avian coccidiosis is a very frequent parasitic disease with a global distribution. The sanitary control of coccidia is very difficult. Indeed, inbreeding, contamination is inevitable and more often multispecific. To date, eight species are known in chickens, and their pathogenicity is a function of the species and receptivity of the host. Fortunately, the presence of the parasite can be well tolerated by the host (Varenina et al., 2017). There are two types of coccidiosis: caecal coccidiosis due to E. tenella and intestinal coccidiosis. The cecum does not play a major role in digestive function and so caecalcoccidiosis is of importance only during clinical disease. Animals lose their appetite, haemorrhagic diarrhoea is noted, and this disease can often lead to death. Intestinal coccidiosisis less serious, and has lower mortality, diarrhoea is not haemorrhagic; however, the decrease in appetite is important. Apart from clinical expression, parasitic development can also disrupt digestive function and alter the general metabolism (such as protein synthesis) which can have consequences on production (increase in the conversion index, heterogeneity of batches).

The economic impact of the disease is estimated at EUR 2.3 billion worldwide, with $70 \%$ of losses attributable to subclinical coccidiosis. This is difficult to diagnose, as it depresses live weight gain and the food consumption index of chicken (Dakpogan et al., 2012). There is currently no method of prophylaxis that can control this parasitism to combat the effects of coccidiosis on the zootechnical performance of broiler chickens and to improve the yield of farms and compensate for economic losses caused by these parasites. All anticoccidials currently known more or less quickly induce resistance or at least decrease ineffectiveness. In this context, in combatting the misuse of antibiotics and anticoccidials, especially given the appearance of resistance, one of the approaches is to allow the host to endure a certain degree of parasitism without compromising production (Yvore, 1992). To this aim, several products have been tested, particularly in the field of biotechnology, including probiotics and prebiotics (Kavazović et al., 2019).

A symbiotic is simply a combination of a probiotic and a prebiotic; the objective is to increase the survival time of the probiotic microorganism by providing it with a substrate for its fermentation (Collins and Gibson, 1999). These mixtures of molecules are the subject of our study, which aims to evaluate 
the impact of their use on zootechnical performance and test their effectiveness on coccidiosis in broiler farms.

The product used in our study is a purely biological food additive for veterinary use intended for animal husbandry. It allows balancing the digestive flora, improving digestion at the gastrointestinal level, strengthening the immune system to maintain a good state of health, and improving the quality of droppings, which makes the environment less aggressive by the smells of gases released from the droppings.

\section{Materials and methods}

\section{Animals and livestock}

The study was conducted on the outskirts of the city of M'sila, a rural area in the centre of the country, 230 $\mathrm{km}$ southeast of Algiers. The study was performed at a modern poultry farm with a capacity of ten buildings in sandwich panels. Buildings were constructed in compliance with European standards, with automatic control of ambient conditions and software that controls all farm parameters (i.e., temperature, humidity, lighting, ventilation, automatic distribution of water and feed) which allows us to eliminate the differences between the buildings.

Animals were distributed in two buildings, each with a capacity of 12,000 chickens of the ArborAcres strain. Chickens in one building received a supplement with a symbiotic in oral form in drinking water, at a weekly dose of $600 \mathrm{~mL}$. Throughout the experiment, all chickens had ad libitum access to feed and water, and uniform breeding conditions.

\section{Symbiotic}

The symbiotic used is a purely biological product composed of plants and plant extracts, probiotic (Lactobacillus acidophilus), prebiotic: digestive and water enzymes, obtained with the patented MENSEN process. The symbiotic was administered in drinking water at the rate of $50 \mathrm{~mL}$ per 1000 chickens, once per week from the start of the experiment, i.e., on days $1,7,14,21,28,35,42$, and 49 .

\section{Parameters Measures}

In this study, two types of parameters were measured: zootechnical performance and parasitic measures.

Zootechnical

performance:

The mortality, the amount of feed and water, and weight of chickens were recorded daily. Weighing was performed automatically using a tray scale. The average weight gain, average food consumption, and the index of consumption were determined at the end of each phase of rearing (Table 1):

- start-up phase lasted from day 1 to 12 (12 days),

- growth phase lasted from day 13 to 30 (18 days), and

- finishing phase lasted from day 31to 42 (12 days).

The composition of feed by phase was the same composition but with different percentages.

Parasitic measures: droppings were harvested directly from the ground of the two buildings randomly in different places of the straw litter once every week (on days $0,7,14,21,28,35,42$ ).Fresh droppings were placed put in small plastic boxes, labelled and stored in the refrigerator at $4{ }^{\circ} \mathrm{C}$.

At the end of breeding, the chickens were slaughtered at M'sila at a modern slaughter line. Intestinal and caecal contents of more than $10 \%$ of chickens of each farm (1250 carcasses from each farm) were recovered and continuous pressure exerted along the entire length of the digestive tract to recover the contents at the exit from the cloacae, which was transferred to large plastic jars, labelled and stored at $4{ }^{\circ} \mathrm{C}$. 
The coprological parasitic study was carried out in two parts:

Part One-identifying and enumerating coccidian oocysts using two qualitative and quantitative methods: the floatation enrichment method and the Macmaster method.

\section{Flotation enrichment method}

This is a qualitative method that makes it possible to highlight coccidian oocyts. It is based on the principle that parasite eggs are less dense and therefore float in solutions whose specific weight is higher than that of the eggs (Sloss et al., 1994). Samples are suspended in sodium chloride (d: 1.2), making it possible to concentrate maximum oocysts in a minimum volume and to more quickly highlight them using microscopic examination. After sieving, the filtrate is recovered in glasses of 1 litter. Then several test tubes are filled from the suspension until a meniscus is formed, slats are placed to avoid trapping air bubbles. After 20 to 30 minutes, the lamella is lifted by bringing the adhering liquid in which the oocysts have gathered, and the entire preparation is examined under an optical microscope at 100x and 400x magnification (Triki-Yamani et al., 2014).

\section{MacMaster method}

This is a quantitative concentration method for counting the number of oocysts per gram of faeces. A total of 5 grams of droppings are suspended in a dense solution of sodium chloride (d: 1.2) to a volume of $75 \mathrm{~mL}$, which is passed through a sieve to remove large particles by sieve filtration. The MacMaster counting cell is filled using a pipette to avoid the formation of air bubbles, and after five minutes, the oocysts float on the surface of the enrichment liquid and adhere to the blade. The oocysts are then counted under the microscope at 100x magnification (Thienpont et al., 1986).
The number of oocysts per gram of OPG droppings is determined using the following formula (Euzeby, 1963):

$$
\mathrm{OPG}=\frac{\mathrm{n} \times 75}{0.3 \times 5}=50 \times \mathrm{n}
$$

(where is total number of oocysts in the two chambers; 75 is the total volume of solution in $\mathrm{mL}$; 5 is the number of droppings weighed; 0.3 is $2 \times 0.15$ as the volume of one chamber in $\mathrm{mL}$ ).

Part two: Culture technique of coccidian oocysts for sporulation

The oocysts found and isolated in the previous methods are placed at the rate of $1 \mathrm{~mL}$ floating in glass Petri dishes and immersed in 5 to $10 \mathrm{~mL}$ potassium dichromate at $2.5 \%$ thin layer and left to incubate at room temperature for 3 and 5 days. The solution is stirred daily to ensure oxygenation of the coccidia. We used an oven for 72 hours at 26$27{ }^{\circ} \mathrm{C}$. After incubation, the solution is centrifuged at $3000 \mathrm{rpm}$, the pellet is recovered by a sedimentation procedure, the supernatant is removed and water is added (Hendrix and Robinson, 2006), then we proceeded to the reading.

\section{Identification of isolated Eimeria species}

The measurement of oocysts is very useful to identify unusual parasites or to differentiate them in case of a similarity of appearance but with different dimensions. To measure these structures, a micrometre is inserted into the eyepiece of the microscope by dividing the lens, is calibrated and the appropriate index calculated (Sloss et al., 1994). Calibration is possible thanks to another compliment: the objective micrometre which is placed on the plate as an ordinary blade with a scale divided into 100 (Lamy, 1970). At the end of these measurements, we applied a morphometric method of identifying 100 coccidian oocysts for each culture using the identification key developed 
by Euzeby (1987). The examination was carried out using the $40 \mathrm{x}$ micrometre.

\section{Statistical analysis}

To compare the results of parameters, the statistics were based on the application of the T-test using the SPSP statistics software for certain parameter values, such as mortality and food consumption, and the study of trend lines for other values such as parasitological results on the other hand, which made it possible to refine the results to better interpret and exploit them later.

\section{Results}

\section{Parasitology}

Flotation: the goal is the search for Coccidia

After sample collection and preparation, we divided the samples from the two farms into three lots for each building, according to age and taking into consideration the cycle of coccidian (Lot 1: day 15, lot 2: day 21, and lot 3: day 28). The reading was performed on 10 blades for each lot (Hendrix and Robinson, 2006; Taylor et al., 2016). In the three control lots, coccidia were detected, with some beginning to sporulate with the formation of sporozygotes. In the treated lots, observation showed that the blades were not crowded, and contained no parasitic elements (Table 1).

\section{Parasite counts: MAC MASTER}

The discovery of oocysts in droppings is a sign of an infestation, but the interpretation of the numerical data of quantitative microscopic coprology must take several factors into account such as symptoms especially diarrhoea as well as intestinal lesions (Triki-Yamani et al., 2014).

\section{Oocyst excretion}

Oocyst excretion in the external environment is expressed by the number of elements found and counted per gram of droppings. The results (Table 2) show an absence of parasites in the droppings harvested in the treated group. In the control group, oocysts began to appear from the $3^{\text {rd }}$ week with a value of 100 OPG. In the $4^{\text {th }}$ week, an increase was observed, with a value of 550 OPG.

\section{Infestation rate}

A difference in values was also observed during the analysis of the intestinal content harvested at slaughter, which was also divided into three lots

Table 1. Flotation results

\begin{tabular}{|c|c|c|}
\hline AGE (days) & Control group & Treatment group \\
\hline 15 & $(-)$ & $(-)$ \\
\hline 21 & $(+)$ some oocysts/fields & $(-)$ \\
\hline 28 & $(+)$ multiple oocysts /fields & $(+)$ some oocysts /fields \\
\hline
\end{tabular}

Table 2. Oocyst excretion

\begin{tabular}{|c|c|c|c|}
\hline Days & Control group (OPG) & Experimental group (OPG) & Impact \\
\hline 15 & 0 & 0 & 0 \\
\hline 21 & 100 & 0 & -100 \\
\hline 28 & 550 & 0 & -550 \\
\hline
\end{tabular}


Table 3. Infestation rate

\begin{tabular}{|c|c|c|c|}
\hline lot & $\begin{array}{c}\text { Control group } \\
\text { (OPG) }\end{array}$ & $\begin{array}{r}\text { Experimental group } \\
\text { (OPG) }\end{array}$ & Impact \\
\hline 1 & 41600 & 800 & -40800 \\
\hline 2 & 32800 & 1100 & -31700 \\
\hline 3 & 30500 & 1200 & -29300 \\
\hline Average & 34966.66 & 1033.33 & \\
\hline
\end{tabular}

The values were significantly lower in the group that received a symbiotic supplement.

for each group (Table 3). For the control group, the values ranged from 30,500 to 41,600 OPG, while for the experimental group, the values ranged from 800 to 1200 OPG.

\section{Identification of oocysts: Prevalence of Eimeria species}

After sporulation, we proceeded with the identification of oocysts. In the control group lots, there were 100 elements necessary for identification, while for the treated batch and after reading several blades, we were able to recover only 10 elements that were isolated and identified (Figures 1 and 2).

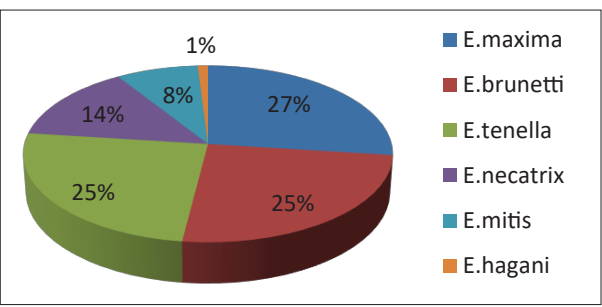

Figure 1. Percentage of Eimeria species in the control group

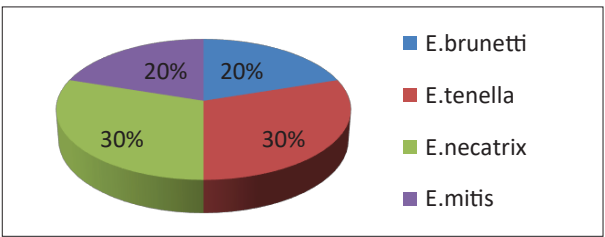

Figure 2. Percentage of Eimeria species in the experimental group
In the control group, we identified six species of Eimeria classified in descending order E. maxima 27\%, E. brunetti and E. tenella, 25\% E. necatrix 14\%; E. mitis with $8 \%$ and finally $1 \%$ for E. hagani.

\section{Zootechnical parameters}

The values of parameters, weights, mortalities, feed, and water consumption were recorded daily, but we grouped them by phase of rearing, start-up, growth and finishing, as outlined in the Materials and methods.

Evolution of mortality: high mortality was observed on the two farms during the first start-up phase in favour of the control group, with 447 vs 502 in the experimental group. Mortality decreased over the next two phases, and at the end of breeding, a total of 1115 dead chicks were recorded for the experimental group and 1285 chicks for the control groups (Table 4).

Using the student's T-test with significance set at $P<5 \%$, no significant differences were found between the mean mortalities of the two groups. However, at a higher confidence level of $10 \%$, significance differences were found, as shown in Table 5.

Indeed, a clear improvement in terms of mortality was observed, especially from the growth phase, with an increasing difference between the two groups, suggesting that supplementation with symbiotic provides gains in the long term. In this aspect of this study, 
Table 4. Evolution of mortality

\begin{tabular}{|c|c|c|c|}
\hline Phase & Experimental group & Control group & Difference \\
\hline Start-up & 502 & 447 & -55 \\
\hline Growth & 301 & 384 & 83 \\
\hline finishing & 312 & 427 & 115 \\
\hline TOTAL & 1115 & 1258 & 143 \\
\hline
\end{tabular}

Table 5. T-test at risk of error $5 \%$ for weight

\begin{tabular}{|c|c|c|c|c|c|c|c|c|c|c|c|}
\hline Mortality & Mean & Mean & t-value & df & $\boldsymbol{P}$ & $\begin{array}{c}\text { Valid } \\
\mathbf{N}\end{array}$ & $\begin{array}{c}\text { Valid } \\
\mathbf{N}\end{array}$ & $\begin{array}{c}\text { Std. } \\
\text { Dev. }\end{array}$ & $\begin{array}{c}\text { Std. } \\
\text { Dev. }\end{array}$ & F-ratio & $P$ \\
\hline $\begin{array}{c}\text { Totalstartcontrol } \\
\text { vs. TotalstartTr }\end{array}$ & 34.38 & 38.61 & -0.49 & 24 & 0.62 & 13 & 13 & 20.76 & 22.67 & 1.19 & 0.76 \\
\hline $\begin{array}{c}\text { Totalgrouthcontrol } \\
\text { vs. TotalgrouthiTr }\end{array}$ & 21.33 & 16.72 & 1.82 & 34 & 0.07 & 18 & 18 & 8.64 & 6.30 & 1.87 & 0.2 \\
\hline $\begin{array}{c}\text { TotalFinicontrol } \\
\text { vs. TotalFiniTr }\end{array}$ & 35.58 & 26.00 & 1.98 & 22 & 0.06 & 12 & 12 & 13.91 & 9.35 & 2.21 & 0.2 \\
\hline
\end{tabular}

Table 6. Evolution of weight

\begin{tabular}{|c|c|c|c|}
\hline Phase & Standardweight $(\mathbf{g})$ & $\begin{array}{c}\text { Experimental group } \\
\mathbf{( g )}\end{array}$ & Control group (g) \\
\hline Start-up & 364 & 337 & 337 \\
\hline Growth & 1705 & 1616 & 1520 \\
\hline Finishing & 2857 & 2590 & 2498 \\
\hline
\end{tabular}

Table 7. T test at risk of error $5 \%$ for weight

\begin{tabular}{|c|c|c|c|c|c|c|c|c|c|c|c|}
\hline weight (g) & Mean & Mean & t-value & df & $P$ & $\begin{array}{c}\text { Valid } \\
\mathbf{N}\end{array}$ & $\begin{array}{c}\text { Valid } \\
\mathbf{N}\end{array}$ & $\begin{array}{l}\text { Std. } \\
\text { Dev. }\end{array}$ & $\begin{array}{l}\text { Std. } \\
\text { Dev. }\end{array}$ & F-ratio & $P$ \\
\hline $\begin{array}{l}\text { weight } \\
\text { starcontrol vs. } \\
\text { weight starTr }\end{array}$ & 151.61 & 151.92 & -0.008 & 24 & 0.99 & 13 & 13 & 94.96 & 95.17 & 1.00 & 0.99 \\
\hline $\begin{array}{l}\text { weight } \\
\text { grouthcontrol } \\
\text { vs. weight } \\
\text { grouthTr }\end{array}$ & 928.11 & 945.83 & -0.141 & 34 & 0.88 & 18 & 18 & 361.82 & 388.06 & 1.15 & 0.77 \\
\hline $\begin{array}{l}\text { weight } \\
\text { Finicontrol vs. } \\
\text { weight FiniTr }\end{array}$ & 2059.25 & 2168.16 & -0.926 & 22 & 0.36 & 12 & 12 & 290.81 & 284.97 & 1.04 & 0.94 \\
\hline
\end{tabular}

we observed the presence of a strong link between the presence of parasites and mortality, where it can be concluded that the excretion of the parasite tends to decrease and is accompanied by a decrease in mortality. 


\section{Weight}

The growth curve evolved in the same manner for both farms during start-up, while remaining lower than the strain standard. However, during growth, we observed that treated subjects showed an improvement in the sharper weight gain that continued during the finishing phase with a value of $2543 \mathrm{~g}$ and $2451 \mathrm{~g}$, or a difference of $92 \mathrm{~g}$.

At slaughter on day 43, all chickens were weighed. The average weight was $2750 \mathrm{~g}$ for chickens in the experimental group and $2630 \mathrm{~g}$ in the control group (the strain norm at the same age is $3043 \mathrm{~g}$ ) (Tables 6, 7 and Figure 3).

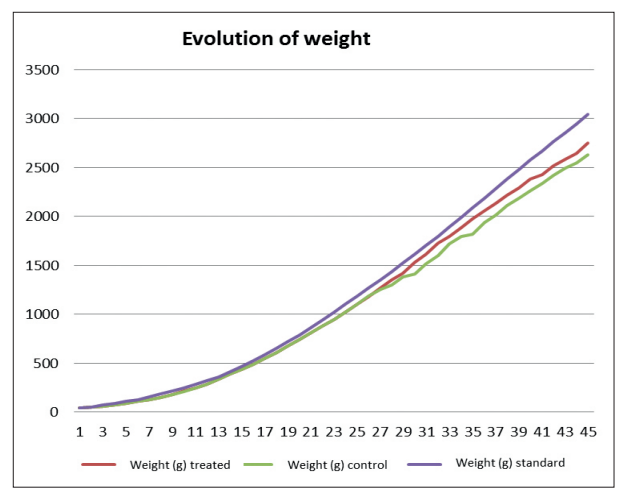

Figure 3. Evolution of weight
Using the T-test with $P<5 \%$, no significant differences were found between the weight means, though a difference between values at the end of rearing was found, which could be explained by the positive effect of symbiotics.

\section{Feed consumption}

The feed consumption curve shows that a difference appears towards the end of rearing, where chickens receiving symbiotics consumed less feed, though this difference was not statistically significant at a confidence level of $5 \%$, except during the finishing phase

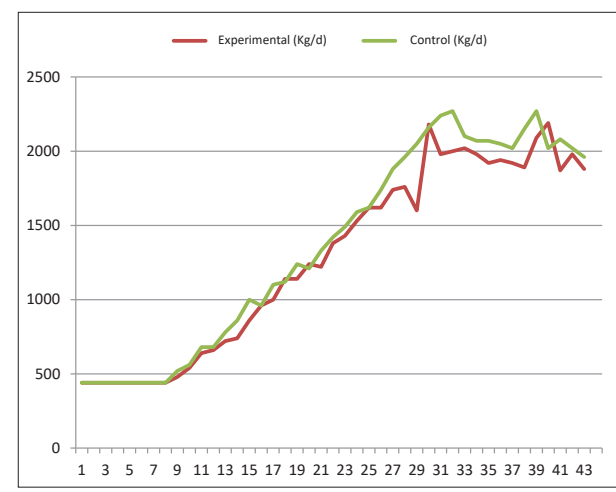

Figure 4. Evolution of consumption (Kg/D)

Table 8. T-test ata 5\% significance level for feed consumption

\begin{tabular}{|c|c|c|c|c|c|c|c|c|c|c|c|}
\hline $\begin{array}{l}\text { Feeding } \\
\text { (kg/day) }\end{array}$ & Mean & Mean & t-value & df & $P$ & $\begin{array}{c}\text { Valid } \\
\mathbf{N}\end{array}$ & $\begin{array}{c}\text { Valid } \\
\mathbf{N}\end{array}$ & $\begin{array}{l}\text { Std. } \\
\text { Dev. }\end{array}$ & $\begin{array}{l}\text { Std. } \\
\text { Dev. }\end{array}$ & F-ratio & $P$ \\
\hline $\begin{array}{l}\text { feedstart- } \\
\text { control vs. } \\
\text { feedcon- } \\
\text { trolTr }\end{array}$ & 518.46 & 504.61 & 0.31 & 24 & 0.75 & 13 & 13 & 119.57 & 101.70 & 1.38 & 0.58 \\
\hline $\begin{array}{c}\text { Feedgrouth- } \\
\text { control vs. } \\
\text { feedcon- } \\
\text { trolTr }\end{array}$ & 1498.33 & 1396.66 & 0.73 & 34 & 0.46 & 18 & 18 & 431.44 & 392.48 & 1.2 & 0.70 \\
\hline $\begin{array}{l}\text { feedFi- } \\
\text { niicontrol vs. } \\
\text { feedcon- } \\
\text { trolTr }\end{array}$ & 2090 & 1961.66 & 3.06 & 22 & 0.005 & 12 & 12 & 96.57 & 108.53 & 1.26 & 0.70 \\
\hline
\end{tabular}

Control Tr: experimental group 
Table 9. Growth parameters for experimental group

\begin{tabular}{|c|c|c|c|}
\hline Phase & $\begin{array}{c}\text { Total } \\
\text { consumption(g) }\end{array}$ & Live weight $\mathbf{( g )}$ & $\mathbf{C l}$ \\
\hline Start-up & 546 & 337 & 1.62 \\
\hline Growth & 2186 & 1616 & 1.35 \\
\hline Finishing & 2102 & 2590 & 0.81 \\
\hline TOTAL & 4834 & & \\
\hline & slaughter weight & 2750 & \\
\hline
\end{tabular}

Table 10. Growth parameters for control group

\begin{tabular}{|c|c|c|c|}
\hline Phase & $\begin{array}{c}\text { Total consumption } \\
\text { (g) }\end{array}$ & Live weight $\mathbf{l g}$ ) & Cl \\
\hline Start-up & 556 & 337 & 1.649 \\
\hline Growth & 2310 & 1520 & 1.519 \\
\hline Finishing & 2221 & 2498 & 0.889 \\
\hline TOTAL & 5087 & & \\
\hline & slaughter weight & 2630 & \\
\hline
\end{tabular}

(Table 8) which could present economic profitability (Figure 4).

\section{Consumption index $(\mathrm{Cl})$}

For the growth parameters, the average weight gain, consumption index, and the conversion index were calculated and classified in the following tables.

Table 11. Conversion index

\begin{tabular}{|c|c|c|}
\hline Phase & $\begin{array}{c}\text { Treated } \\
\text { breeding }\end{array}$ & $\begin{array}{c}\text { Control } \\
\text { breeding }\end{array}$ \\
\hline Weight gain & $2543 \mathrm{~g}$ & $2451 \mathrm{~g}$ \\
\hline $\begin{array}{c}\text { Total } \\
\text { consumption }\end{array}$ & $4834 \mathrm{~g}$ & $5087 \mathrm{~g}$ \\
\hline $\begin{array}{c}\text { conversion } \\
\text { index }\end{array}$ & 1.90 & 2.07 \\
\hline
\end{tabular}

The CI was better in all three 3 phases for the experimental group, due to the beneficial effect of the symbiotic on digestive health (microbiota and mucosa) with improved digestibility and absorption of nutrients, which consequently improves the consumption index.

\section{Conversion index}

The following table shows the conversion index.

The feed conversion index value was also better for the experimental group, with a value of 1.90 compared to the control group with a value of 2.07. The results suggest that the use of symbiotic appear to improve feed efficiency with a better conversion index.

\section{Water consumption}

The consumption of drinking water at the two farms was nearly identical by at the end of breeding with a volume of 9.55 litres for chickens in the experimental group and 9.48 litres for the control group. In the finishing phase, the difference was statistically significant $(P<0.5)$ (Table 12). 
Table 12. Water consumption

\begin{tabular}{|c|c|c|}
\hline Days & Water (L/d) control & Water (L/d) experimental \\
\hline Start-up & 12028 & 11805 \\
\hline Growth & 46580 & 46626 \\
\hline Finishing & 43500 & 45954 \\
\hline Cumulative & 102108 & 104385 \\
\hline Average water consumption & 9.55 L/animal & 9.48 L/animal \\
\hline
\end{tabular}

\section{Discussion and conclusions}

The modern design of the buildings and automated control of ambient parameters allows all difference due to extrinsic factors between the two groups to be eliminated. The incorporation of certain natural products could have practical applications, and indeed more studies are showing the positive effects of medicinal plants, used for a long time in other fields, such as in human medicine (Crevieu-Gabriel and Naciri, 2001).

Like all broiler farms, these two farms have incidences of parasites and the study results indicate the presence of Coccidia. Broiler chickens have parasites, regardless of the month or season (Hachimi et al., 2008). In this study, animals receiving a supplement symbiotic showed a clear decrease in intestinal parasitism with very low rates, we noted a rate of oocyst excretion of zero during the first 4 weeks. For infestation rates, the rates in the control group was 33.83 times higher than compared to the experimental group. This may be due to the positive effects of the symbiotic and its effectiveness on coccidiosis. Similar results have been found in other studies showing a reduction of oocyst excretion following the use of probiotics compared to controls (Behnamifar et al., 2019).

Regarding the species found in the control group, subclinical coccidiosis in broilers are frequently caused by $E$. maxima and E. acervulina (Jordon and Pattison, 1996), suggesting subclinical coccidiosis infestation by several species.
Studies on the pathogenicity of Coccidia have made it possible to classify them on the basis of their pathogenicity ( $E$. tenella++++, E. necatrix,++++ E. brunetti+++, E. maxima+++, E. acervulina++, E. mitis + ) (Euzeby, 1987). The 5 least pathogenic species are E. hagani, E. mitis, E. praecox, E. mivati and E. aceroulina (McDougald and Fritz-Coy, 2008). The presence of E. tenella as the second most prevalent, together with E. brunetti indicates that it is a more or less significant infestation, though the absence of symptoms during this study evoking the disease suggests that the rate of infestation by these species has not reached the lethal threshold of 18,200 OPG for E. brunetti, 63,000 OPG for E. necatrix, and 16,300 OPG for $E$. tenella, which are responsible for clinical expression. In terms of mortality, the latter is related to the intensity of oocyst excretion of the parasitic load. Dakpogan et al. (2012) obtained a mortality rate of $100 \%$ with a dose of 1.000.000 OPG E. tenella and E. necatrix. The rates found in the present study may explain the higher mortality rates obtained in the control group, and particularly during the growth and finishing phases. The difference in averages in the growth and finishing phases were significant in favour of the experimental group, presents a source of economic gain and supporting other studies on the combination of probiotics and prebiotics in increasing the survival rate of broilers by modulating intestinal health conditions and decreasing lesion scores (Hussein et al., 2020). 
On the other hand, the mortality revealed in the start-up phase, particularly during the initial days after the chicks were installed, could be explained by the stress associated with transport to the holding, and the handling of chicks during set-up. In addition to the decrease in mortality, a decrease in feed consumption was also observed during the three phases, with a significant value in finishing with improved performance, indicating that the use of the symbiotic improved the feed conversion index and presenting an interesting economic gain in the breeding of broiler chickens.

Symbiotics act on the presence of parasites and on infestation rates. They also act positively on the intestinal microbiota, thus improving health and performance. Treated livestock showed an improvement in terms of mortality and consumption of water and feed. Other factors (diet, environmental parameters in livestock buildings, the composition of the symbiotic and its dosage) must be examined in greater depth to improve the results obtained.

The average weight of broilers obtained at the end of rearing was 2630 $\mathrm{g}$ for the control group and $2750 \mathrm{~g}$ for the experimental group. This difference confirms the results of different studies that showed the positive effect of symbiotics on the growth parameters of broilers (Jin et al., 1998; Mountzouris et al., 2007).

It is well known that coccidiosis is characterized by a reduction in ingestion and weight gain, and an increase in the consumption index (Crevieu-Gabriel and Naciri, 2001). The presence of a very high infestation rate in the control group could also explain the difference between values of growth and conversion indices in favour of the experimental group. Other studies have concluded that the effects of symbiotics on weight gain begin to be significant towards the end of breeding (Mountzouris et al., 2007).
It is in this sense that probiotics are recommended as a potential alternative to antimicrobials in the diet of chickens, especially in the growth and finishing phases (Xang et al., 2016).

Under normal breeding conditions, CI is between 1.9 and 2.1, and this increased following the development of coccidiosis in the host (Hachimi et al., 2008). On the farms included in this study, we noted better rates, which could be due to the control of the ambient parameters and breeding in a modern infrastructure, in addition to the use of symbiotics in drinking water of the treated group that positively impacted performance.

Jin et al. (1998) indicated that the use of a probiotic based on cultures of lactobacilli LC (the main constituent of our symbiotic) in broilers significantly improved weight gain at certain concentrations but not at others, especially from the $3^{\text {rd }}$ week. Knowing that the indigenous flora has effects on the animal at many levels, it prevents the implantation of pathogenic flora. This phenomenon, called the "barrier effect", in particular with the lactobacilli that produce bacteriocins, acidify the $\mathrm{pH}$ of the environment, leading to a bactericidal effect that limits the growth of harmful bacteria (Gabriel et al., 2003). And since parasitism and coccidiosis, in general, weaken their host and often induce bacterial superinfections, probiotics could reduce their side effects by this barrier effect.

In conclusion, this study on the effect of symbiotic in broilers has revealed very interesting positive effects that could revive modern breeding, which has a goal of intensifying production while preserving public health by limiting the use of antibiotics. Our data show that symbiotics act well on the presence of Coccidia and cause a decrease in infestation with a resulting increase in yield, decrease in mortality, and better indices of feed and water 
consumption. However, further study is required, particularly on the choice of probiotic-prebiotic couples for use and their respective levels in the mixture to improve their impact on animal health and yields and consequently on human health.

\section{References}

1. BEHNAMIFAR, A. R., S. RAHIMI, M. M. KIAEI and H. FAYAZII (2019): Comparison of the effect of probiotic, prebiotic, salinomycin and vaccine in control of coccidiosis in broiler chickens. Iran. J. Vet. Res. 20, 51-54.

2. BRUGERE-PICOUX, J. and A. SILIM (1992): Tableaux récapitulatifs des principales maladies aviaires. - Manuel de pathologie aviaire, édit. J. Brugere-Picoux, A. Silim, pp. 375-381.

3. COLLINS, M. and G. GIBSON (1999): Probiotics, prebiotics and synbiotics: approaches for modulating the microbial ecology of the gut. Am. J. Clin. Nutr. 69, 1052-1057.

4. CREVIEU-GABRIELI, I. and M. NACIRI (2001): Dietary effect on chicken coccidiosis. INRA Prod. Anim. 14, 231-246.

5. DAKPOGAN, H. B., S. SALIFOU, G. A. MENSAH, A. GBANGBOTCHE, I. YOUSSAO, M. NACIRI and N. SAKITI (2012): The problem of control and prevention of chicken coccidiosis. Int. J. Biol. Chem. 6, 6088-6105.

6. EUZEBY, J. (1987): Protozoologie médicale comparée. Vol. II collection fondation marcel MERIEUX, Lyon, 1987, pp. 110-201.

7. EUZEBY, J. (1963): Verminousdiseases of domesticanimals and their impact on humanpathology; tome I maladies dues aux Némathelminthes, fascicule deuxième, Vigot frères éditeurs, Paris, pp. 100-203.

8. GABRIEL, I., S. MALLET, M. LESSREM and J. F. GUILLOT (2003): Digestive microflora: a forgotten component of poultry nutrition. World Poultry Sci. J. 62,3 .

9. GUERGUEB, N., N. ALLOUI, I. CHACHOUA, A. AYACHI, O. BENNOUN and L. AOUN (2020): Impact of hygienic slaughter practices on Salmonella contamination of broiler carcasses in Biskra, Algeria. Vet. stn. 51, 463-470.

10. GUERGUEB, N., N. ALLOUI, A. AYACHI, L. AOUN and I. CHACHOUA (2021): Factors Associated with Bacterial Contamination of Poultry Meat at Butcher Shops in Biskra, Algeria. Vet. stn. 52, 429-437.

11. HACHIMI, M., D. BELGHYTI, K. ELKHARRIM and Y. EL GUAMRI (2008): Chicken coccidiosis in the Gharb region (MOROCCO). Bulletin de la SociétéPharmacie de Bordeaux 147, 49-60.

12. HENDRIX, M. C. and E. ROBINSON (2006): Diagnostic Parasitology for Veterinary Technicians. $3^{\text {rd }}$ editions, Mosby Elsevier, p. 285.
13. HUSSEIN, E. O. S., S. H. AHMED, A. M. ABUDABOS, G. M. SULIMAN, M. E. ABD ELHACK, A. A. SWELUM and A. N. ALOWAIME (2020): Ameliorative Effects of Antibiotic-, Probiotic- and Phytobiotic-Supplemented Diets on the Performance, Intestinal Health, Carcass Traits, and Meat Quality of Clostridium perfringens-Infected Broilers. Animals (Basel) 10, p. 669.

14. JIN, L. Z., Y. W. HO, N. ABDULLAH and S. JALALUDIN (1998): Growth performance, intestinal microbial populations and serum cholesterol of broilers fed diets containing Lactobacillus cultures. Poult. Sci. 77, 1259-1265.

15. JORDON, F. T. W. and M. PATTISON (1996): Poultry disease. W. B. Saunders Company Ltd. London, p. 497.

16. KAVAZOVIĆ, A., E. REŠIDBEGOVIĆ, A. GAGIĆ, F. ALIBEGOVIĆ-ZEČIĆ, T. GOLETIĆ, Ć. CRNKIĆ, A. SOFTIĆ, A. KUSTURA and A. KORO (2019): Effect of commercial and experimental probiotics on immune response to Infectious Bursal Disease vaccination in broiler chickens. Vet. stn. 50, 27-32. (In Croatian).

17. LAMY, L. (1970): Diagnosis of parasitoses a Protozoa and Helminths in the laboratory; $2^{\text {nd }}$ ed. basic technical collection, editions de la Tourelle.

18. MCDOUGALD, L. R. and S. H. FITZ-COY (2008): Coccidiosis. In: Y. M. Saif, (eds.), Disease of poultry, $12^{\text {th }}$ edn., Blackwell Publishing, Ames, IA, USA, pp. 1068-1080,

19. MOUNTZOURIS, K. C., P. TSISTSIKOS, E. KALAMARA, S. NITSH, G. SCHATZMAYR and K. FEGEROS (2007): Evaluation of the efficacy of a probiotic containing Lactobacillus, Bifidobacterium, Enterococcus, and Pediococcus strains in promoting broiler performance and modulating cecalmicroflora composition and metabolic activities. Poult. Sci. 86, 309-317.

20. SLOSS, M. W., R. L. KEMP and A. M. ZAJAC (1994): Veterinary Clinical Parasitology. $6^{\text {th }}$ edition, American association of veterinary parasitologists, pp. 120-250.

21. TAYLOR, M. A., R. L. COOP and I. WALL (2016): Veterinary parasitology, $4^{\text {th }}$ edition, WilleyBlackwell, Chichester, West Sussex, UK, pp. 637-764.

22. THIENPONT, D., F. ROCHETTE and O. VANPARIJS (1986): Diagnosing helminthiasis by coprological examination. Belgium: Janseen Research Foundation.

23. TRIKI-YAMANI, R. R., R. M. SAID, F. BENAISSA, M. BACHIR-PACH and A. BOUYOUCEF (2014): The coccidiosis of the broiler in the sub-Saharan regions (Biskra-Algeria). Bulletin UASVM Veterinary Medicine 71, 237-241.

24. VARENINA, I., N. BILANDŽIĆ, Đ. BOŽIČ LUBURIĆ, B.SOLOMUN KOLANOVIĆ, I. VARGA and R. BECK (2017): Residues of coccidiostats in products of animal origin after administration in poultry. Vet. stn. 48, 451-463. (In Croatian).

25. XANG, X., Y. Z. FERNELL, E.D. PEEBLES, A. S. KIESS, K. G. S. WAMSLEY and W. ZHAI 
(2016): Addicts of prebiotics, probiotics and their combination on growth performance, the small intestine morphology and resident Lactobacillus of male boilers. Poult. Sci. 95, 1332-1340.
26. YVORE, P. (1992): Coccidiosis in Poultry Farming. Manuel de pathologie aviaire, édit. J. BrugerePicoux, A.Silim, pp. 257-260.

\section{Učinci simbiotika na infestaciju kokcidima i zootehničku učinkovitost u tovnih pilića}

Chama AMMARI, Mohamed MELIZI, Department of Veterinary Medicine, Laboratory of Animal Health, Animal Production, and Environment (ESPA), Institute of Veterinary Sciences and Agricultural Sciences, University of Batna 1, Batna 05000, Algeria; Nora MIMOUNE, National High School of Veterinary Medicine, El-Alia, Algiers, Algeria, Laboratory of Biorechnologies related to animal reproduction (LBRA), Institute of Veterinary Sciences, SaadDahleb University, Blida, Algeria; Rachid KAIDI, Laboratory of Biorechnologies related to animal reproduction (LBRA), Institute of Veterinary Sciences, SaadDahleb University, Blida, Algeria; Djamel KHELEF, National High School of Veterinary Medicine, Animal Health and Productions Laboratory, ElAlia, Algiers, Algeria

U Alžiru, kao i svugdje u svijetu, kokcidioza i dalje predstavlja problem za ekonomiju u peradarskom sektoru. U području biosigurnosti hrane, uporaba simbiotika ima za cilj poboljšati zootehničku učinkovitost u pilića i borbu protiv negativnih učinaka ove parazitoze. Naša je studija usporedila dvije farme tovnih pilića s 12.000 pilića ARBOR ACRES soja, od kojih je jedna kao dodatak rabila simbiotike. Zamijećeni su: masa (144 pilića), mortalitet, potrošnja hrane i vode. Izračunati su: potrošnja (CI) i indeksi konverzije. Za parazitologiju je prikupljeno $10 \%$ od ukupne količine fecesa i sadržaja crijeva. Podatci su pokazali masu od $2750 \mathrm{~g} \mathrm{u}$ danu 43 za grupu s dodatkom simbiotika u usporedbi s 2630 g (bez dodatka) za prosječnu potrošnju od $4834 \mathrm{~g} /$ subjektu, odnosno 5087g/subjektu;
CI od $(1,62-1,35-0,81)$ u usporedbi s $(1,65$ $-1,52-0,89)$; indeks konverzije $(1,9)$ u odnosu na $(2,07)$; stopu mortaliteta $(9,29 \%)$ u odnosu na 10,37\%. Ekskrecija je oocista na tretiranoj farmi bila u usporedbi s $(0,100 \mathrm{i}$ 550 OPG, u danu 15, 21 i 28) za kontrolnu skupinu; infestacija parazitima (41.600 OPG, 32.800 OPG i 30.500 OPG) u usporedbi s (800 OPG, 1.100 OPG i 1.200 OPG). Što se tiče prevalencije, nekoliko vrsta Eimeria identificirano je u kontrolnoj skupini. Dobiveni prosjeci $\mathrm{u}$ ovom radu govore $\mathrm{u}$ korist uporabe simbiotika. Pretpostavlja se da ćemo, ukoliko budemo radili na poboljšanju formule simbiotika, postizati i bolje rezultate.

Ključne riječi: simbiotici, kokcidioza, zootehnička učinkovitost, stopa infestacije 